\title{
Dispersal and larval hosts of the zigzag elm sawfly Aproceros leucopoda (Hymenoptera) in Slovakia, Central Europe
}

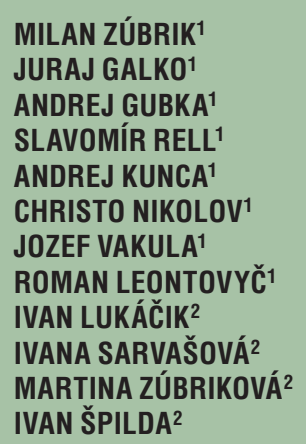

List of nonstandard abbreviations No nonstandard abbreviations were used

Key words: Hymenoptera, UImus spp., Ophiostoma, invasive species, biological invasions, forest pests, Central Europe

Received May 12, 2016

Revised November 9, 2016.

Accepted March 24, 2017.

\begin{abstract}
Background and purpose. The zigzag elm sawfly, Aproceros leucopoda (Hymenoptera), originating from Asia is being considered as one of the major pests of elm trees (Ulmus spp.) within Europe where it was first recorded in 2003. Recent investigations document the fast spread of this invasive species in many European countries. In Slovakia, A. leucopoda was first recorded in 2009 but its occurrence here has not been reported since 2009. Herein, we summarize the data from the two consecutive years about the current distribution of A. leucopoda and its hosts in Slovakia, Central Europe, focusing on infestation of elm trees by this successful invader in different altitudes.
\end{abstract}

Material and methods. In 2014 and 2015 the investigations of A. leucopoda were conducted at 101 different plots across the country. At each plot, characteristic symptoms of leaf damage, occurrence of larvae, cocoons or adults were recorded along with the geographical coordinates and the altitude, and the host trees of $\mathrm{A}$. leucopoda were identified at the species level. The distribution map of A. leucopoda was drawn using the field data. The infestation of elm trees along the altitudinal gradient was analyzed with Kruskal-Wallis non-parametric analysis of variance followed by post-hoc Dunn's test for multiple comparisons.

Results and conclusions. The zigzag elm sawfly A. leucopoda was observed at 31 plots $(30.7 \%, n=101)$. In elm trees examined, generally, a low level of infestation by this pest was observed. A. leucopoda was found at plots between 107 and $701 \mathrm{~m}$ a.s.l. The result show that the infestation level of elm trees was decreasing with increasing altitude. Although we had only a small sample of data, we assume that the altitude has a significant effect on distribution of this pest. The field elm (Ulmus minor Mill.) was the most frequently utilized host. Data collected document the establishment of this successful invader in Slovakia.

\section{INTRODUCTION}

ver the last century, a large number of invasive insect species have become established in Europe (1). Many of them cause severe economical and aesthetical damage to trees in forests and/or urban areas. From those species which recently invaded Slovakia we can mention the horse chestnut leafminer Cameraria obridella Deschka \& Dimic, 1986 (Lepidoptera: Gracillariidae) $(2,3)$, the ambrosia beetle Xylosandrus germanus Blandford, 1894 (Coleoptera: Curculionidae, Scolytinae) (4), or the box tree moth Cydalima perspectalis Walker, 1859 (Lepidoptera, 
Pyralidae) (5). The wide spread of the harlequin ladybird beetle Harmonia axyridis Pallas, 1773 (Coleoptera, Coccinellidae) in Europe including Slovakia is cause of concern, as it is a threat to native species and biodiversity (6).

In 2007, the zigzag elm sawfly Aproceros leucopoda Takeuchi (Hymenoptera: Argidae) was found in Slovakia (7) for the first time. This species has an Asiatic origin. It was described from Hokkaido, Japan by Takeuchi (8). It also occurs in China (9) and Russian Far East (10) but this last record requires taxonomic confirmation (7). In Europe, it was first recorded in Hungary and Poland in 2003. Later on, A. leucopoda was found in Austria, Romania and Ukraine (7). In 2009, the sawfly was reported from Italy (11). Its occurrence in Germany (12), Slovenia (13), Croatia (14), Belgium (15), Serbia (16), the Netherlands (17), the Czech Republic (18), Latvia (19) and Bulgaria (20) was also documented. A. leucopoda occurs in the European part of Russia $(21,22)$.

A. leucopoda is an oliphagous pest which feeds on elm trees (Ulmus spp.). The larvae were collected from $U$. pumila and U. japonica in Japan $(7,8)$. Within Europe, A. leucopoda feeds on native (U. glabra, U. laevis, U. minor) and few cultivated species of elm trees $(7,11,20)$. In European part of Russia larvae develop mainly on Siberian elm U. pumila $(21,23)$.

The populations of elm trees (Ulmus spp.) within Europe have declined considerably since the 1920s. The spread of the vascular wilt disease of elm trees, the Dutch elm disease, resulted in two massive and very destructive pandemics killing most of the European elm trees. The first pandemic, caused by the fungus Ophiostoma ulmi (Buisman) Nannf., occurred between the 1920s and the 1940s. The second (current) pandemic is caused by Ophiostoma novo-ulmi Brasier which has been spreading to regions previously affected by $O$. ulmi $(24,25,26)$. These fungi, transmitted mainly by bark beetles of the genus Scolytus (Coleoptera, Curculionidae, Scolytinae), are responsible for the decline of elm trees in Slovakia too (27, 28). As a result of Dutch elm disease, during the last century elms suffered major losses worldwide, with the neartotal disappearance of adult trees in many European, Asian and North American areas (29).

Observations from Japan show that A. leucopoda is a parthenogenetic species; no males were recorded in the population of this pest (7). During pest monitoring in Italy also only females were collected (11). In Hungary, adults occur from the middle of April till early September (7). In Italy, the first females appeared in the second half of April (from 22 April) and cocoons were found at the beginning of May (from 6 May). The Italian A. leucopoda completes the first generation in mid May, in about 28 days, and the species is multivoltine. In northern Italy the species develops four generations per year, or more (11). Females lay eggs into the edge of leaves. Larvae hatch after 4-8 days and young feeding larvae excavate a very characteristic „zig-zag“ pattern on leaves. Feeding galler- ies lead from the leaf edge to the main vein and usually do not cross side veins $(7,30)$. Larvae make either loosely spun cocoons, or more solid, compact cocoons build in the field in the litter or soil. They overwinter in the more solid cocoons. In loosely spun cocoons eonymphs pupate during 2-3 days and adults emerge after 4-7 days. In Europe, A. leucopoda has four generations per year (7). High number of generations, asexual reproduction and high fertility of females (one female can lay as many as 49 eggs) (7) makes this species a potentially serious pest (defoliator) of elm trees within Europe.

In 2007 and 2009, A. leucopoda was first recorded in Slovakia, Central Europe (7). Since then its occurrence has not been reported from this country at all. This is why we studied the current distribution and hosts of A. leucopoda in Slovakia with emphasis on infestation of elm trees by this pest in different altitudes.

\section{MATERIALS AND METHODS}

\section{Recording, collecting and rearing of $A$. leucopoda}

In 2014 and 2015, from May to August, A. leucopoda was recorded on elm trees growing singly or in small groups at 101 plots along the roadsides and rivers, at the forest edges, inside the forests and in urban areas. The records of the pest at plot distant at least $500 \mathrm{~m}$ from each other were considered as separate observations. For each plot the geographical coordinates were taken and data about the altitude were gathered. Elm species were identified according to Pagan and Randuška (1988) (31). At each plot, characteristic symptoms of leaf damage, occurrence of larvae, cocoons or adults of A. leucopoda were recorded.

Larvae and adults were collected in the field. Field collected larvae were reared on elm foliage in 21 plastic rearing boxes. Leaves very changed every second day, together with the absorbent paper lining on the bottom of the box. Leaves were kept in a small plastic epruvetes filled with water to keep them fresh as long as possible. Larvae were kept in the laboratory under room conditions until morphing into pupa. After pupation, elm leaves with cocoons were collected and placed in Petri dishes $(15 \mathrm{~cm}$ in diameter) until the adults emerged. The larvae and adults were identified using the key by Blank et al. (2010) (7).

\section{Data analysis}

At each plot the elm trees were visually examined for presence of $A$. leucopoda symptoms, always by two people. The samples were taken from lower branches from randomly selected trees. Four levels of infestation (IL0, IL1, IL2, IL3) were recognized judging from occurrence of the pest (larvae, cocoons, adults) and/or its feeding traces (marks) on leaves and trees, respectively. The criteria determining the level of infestation are given in Table 1. 
Table 1. Parameters used to determine the level/degree of infestation of elm trees by A. leucopoda. Achievement of at least one of the given criteria decided about the resulting categorization.

\begin{tabular}{|lcccc|}
\hline $\begin{array}{l}\text { Infestation level } \\
\text { (IL) }\end{array}$ & $\begin{array}{c}\text { Presence of } \text { A. leucopoda (larvae, cocoons and adults) } \\
\text { on leaf surface }\end{array}$ & $\begin{array}{c}\text { Presence of zig-zag pattern on } \\
\text { leaves of the same tree }\end{array}$ & $\begin{array}{c}\text { Defoliation } \\
\text { of trees }\end{array}$ \\
\hline $\begin{array}{l}\text { Not infested } \\
\text { Low }\end{array}$ & 0 & no larva or no cocoon or no adult & Not present & any visible defoliation \\
one larva or one cocoon or one adult & any visible defoliation \\
Intermediate & 2 & $\begin{array}{c}\text { more than one larva or more than one cocoon } \\
\text { or more than one adult }\end{array}$ & from 5 to 29 leaves infested & any visible defoliation \\
High & 3 & $\begin{array}{c}\text { more than } 30 \text { larvae or more than } 30 \text { cocoons } \\
\text { or more than } 30 \text { adults }\end{array}$ & 30 or more leaves infested & at least $5-10 \%$ \\
\hline
\end{tabular}

Achievement of at least one of these criteria decided about the resulting categorization of individual observations into one of the four levels of infestation (Table 1). A plot was categorized to the specific category (level of infestation) after 20 minutes of visual inspection of host trees.

The difference in altitude between infestation levels (IL) was analyzed with Kruskal-Wallis non-parametric analysis of variance followed by post-hoc Dunn's test for multiple comparisons. Data were analyzed using $\mathrm{R}$ version 3.3.1 (32) and 'plot.kw': R function for visually displaying Kruskal-Wallis test's results (33).

The distribution map of $A$. leucopoda was drawn in ArcGIS (ESRI Inc.) using the geographic coordinates of particular plots and the species records.

The average infestation level was calculated as an average of the individual infestation levels of the plots where the pest has occurred.

\section{RESULTS AND DISCUSSION}

\section{Distribution of A. leucopoda in Slovakia}

Over the period 2014-2015, the occurrence of $A$. leucopoda was observed at 101 plots across the whole country. The species was recorded at 31 plots (30.7\%). Following the first observations in 2014, the frequency of observations increased in 2015. In most localities, $A$. leucopoda was identified by conspicuous characteristic „zig-zag” feeding larval traces on leaves. However, the larvae or cocoons were also found. The currently known distribution of A. leucopoda in Slovakia is shown in Figure 1.

As can be seen from Figure 1, most of the records of this species come from the southwest of the country (Figure 1).

Despite of the records of $A$. leucopoda in eastern Slovakia in 2007 (7), the species was not recorded there again

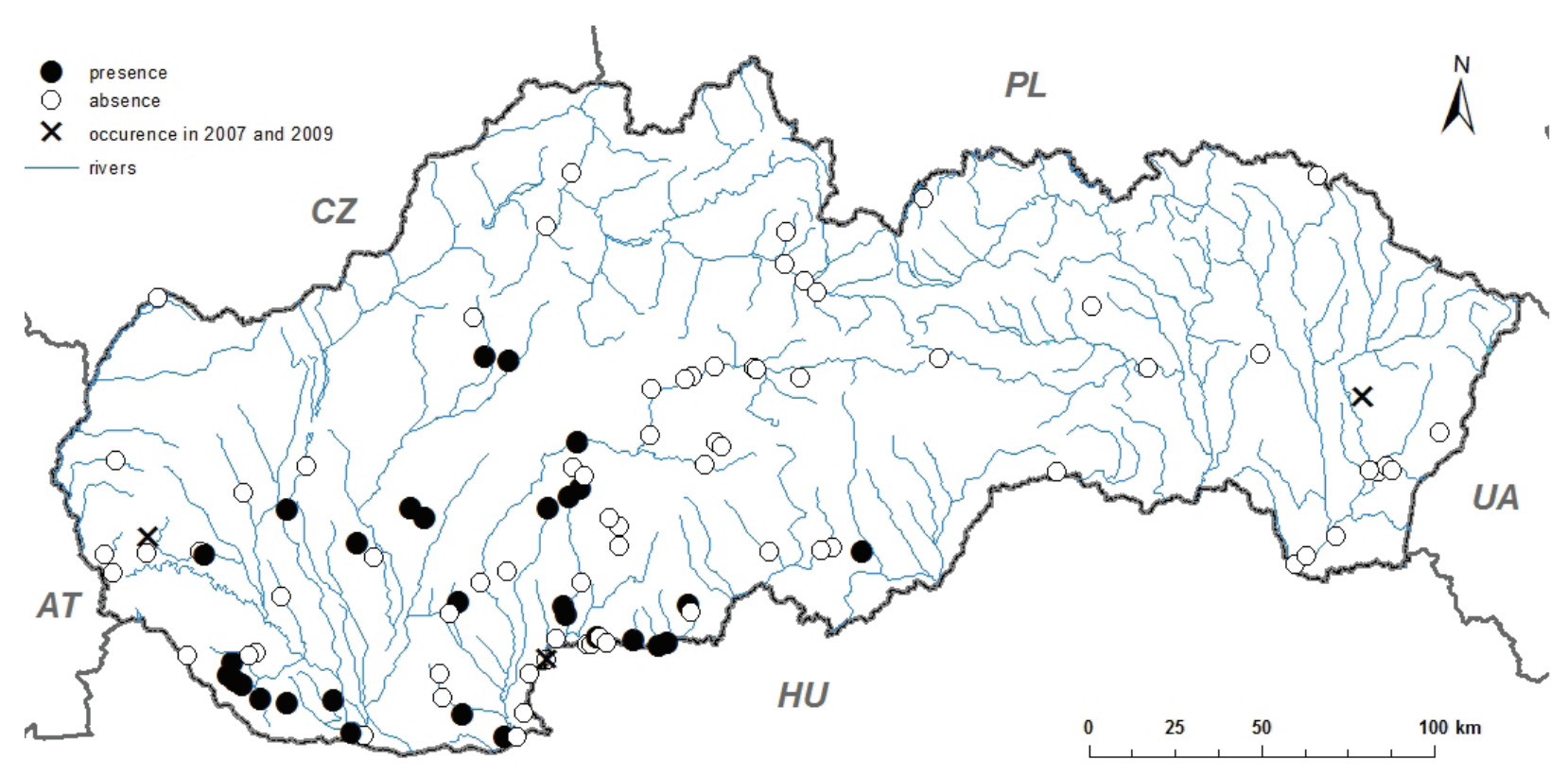

Figure 1. Distribution of A. leucopoda in Slovakia between 2014 and 2015 (presence - filled circles, absence - empty circles) and occurrence of the species in 2007 and 2009 (crosses) (7). 
Table 2. Plots with occurrence of A. leucopoda and their characteristics.

\begin{tabular}{|c|c|c|c|c|c|c|}
\hline District & Character of plot & Latitude & Longitude & Infestation level & Tree species & $\mathrm{m}$ a.s.l. \\
\hline Balog nad Iplom & near road & $48.076^{\circ} \mathrm{N}$ & $19.150^{\circ} \mathrm{E}$ & 2 & $U$. minor & $138 \mathrm{~m}$ \\
\hline Banská Štiavnica & urban area & $48.461^{\circ} \mathrm{N}$ & $18.900^{\circ} \mathrm{E}$ & 1 & Ulmus spp. & $619 \mathrm{~m}$ \\
\hline Beladice & near pond & $48.349^{\circ} \mathrm{N}$ & $18.303^{\circ} \mathrm{E}$ & 2 & $U$. minor & $176 \mathrm{~m}$ \\
\hline Bodza & $\begin{array}{l}\text { urban area, } 150 \text { meter from } \\
\text { water canal }\end{array}$ & $47.837^{\circ} \mathrm{N}$ & $17.829^{\circ} \mathrm{E}$ & 2 & U. minor & $111 \mathrm{~m}$ \\
\hline Bojnice & castle park & $48.778^{\circ} \mathrm{N}$ & $18.576^{\circ} \mathrm{E}$ & 2 & Ulmus spp. & $312 \mathrm{~m}$ \\
\hline Cabaj - Čápor & forest edge & $48.270^{\circ} \mathrm{N}$ & $18.045^{\circ} \mathrm{E}$ & 2 & $U$. minor & $219 \mathrm{~m}$ \\
\hline Čiližská Radvaň & wet forest & $47.842^{\circ} \mathrm{N}$ & $17.729^{\circ} \mathrm{E}$ & 3 & U. minor & $115 \mathrm{~m}$ \\
\hline Dolný Pial & roadside & $48.138^{\circ} \mathrm{N}$ & $18.460^{\circ} \mathrm{E}$ & 1 & U. minor & $181 \mathrm{~m}$ \\
\hline Gabčíkovo & forest edge & $47.896^{\circ} \mathrm{N}$ & $17.592^{\circ} \mathrm{E}$ & 3 & U. minor & $117 \mathrm{~m}$ \\
\hline Gabčíkovo-Pataš & roadside & $47.882^{\circ} \mathrm{N}$ & $17.625^{\circ} \mathrm{E}$ & 2 & U. minor & $115 \mathrm{~m}$ \\
\hline Gbelce & urban area & $47.850^{\circ} \mathrm{N}$ & $18.509^{\circ} \mathrm{E}$ & 2 & U. minor & $132 \mathrm{~m}$ \\
\hline Hadovce & open forest near the village & $47.776^{\circ} \mathrm{N}$ & $18.092^{\circ} \mathrm{E}$ & 3 & $U$. minor & $110 \mathrm{~m}$ \\
\hline Hokovce & forest & $48.153^{\circ} \mathrm{N}$ & $18.870^{\circ} \mathrm{E}$ & 1 & U. minor & $138 \mathrm{~m}$ \\
\hline Horné Semerovce & castle park & $48.127^{\circ} \mathrm{N}$ & $18.882^{\circ} \mathrm{E}$ & 1 & $U$. minor & $130 \mathrm{~m}$ \\
\hline Jelenec & agricultural land & $48.372^{\circ} \mathrm{N}$ & $18.243^{\circ} \mathrm{E}$ & 2 & U. minor & $213 \mathrm{~m}$ \\
\hline Kameničná & marshland & $47.857^{\circ} \mathrm{N}$ & $18.010^{\circ} \mathrm{E}$ & 2 & U. minor & $108 \mathrm{~m}$ \\
\hline Koláre & river bank & $48.074^{\circ} \mathrm{N}$ & $19.272^{\circ} \mathrm{E}$ & 1 & U. laevis & $138 \mathrm{~m}$ \\
\hline Králová pri Senci & roadside & $48.205^{\circ} \mathrm{N}$ & $17.458^{\circ} \mathrm{E}$ & 2 & U. minor & $120 \mathrm{~m}$ \\
\hline Kurinec & forest & $48.350^{\circ} \mathrm{N}$ & $20.024^{\circ} \mathrm{E}$ & 1 & U. laevis & $208 \mathrm{~m}$ \\
\hline Malý Krtíš & agricultural land & $48.180^{\circ} \mathrm{N}$ & $19.355^{\circ} \mathrm{E}$ & 1 & U. minor & $187 \mathrm{~m}$ \\
\hline Nitrianske Rudno & near road & $48.781^{\circ} \mathrm{N}$ & $18.482^{\circ} \mathrm{E}$ & 1 & Ulmus spp. & $319 \mathrm{~m}$ \\
\hline Pataš & urban area & $47.876^{\circ} \mathrm{N}$ & $17.653^{\circ} \mathrm{E}$ & 3 & U. minor & $113 \mathrm{~m}$ \\
\hline Slovenské Ďarmoty & river bank & $48.076^{\circ} \mathrm{N}$ & $19.280^{\circ} \mathrm{E}$ & 3 & U. minor & $137 \mathrm{~m}$ \\
\hline Štiavnické Bane & near lake & $48.435^{\circ} \mathrm{N}$ & $18.857^{\circ} \mathrm{E}$ & 1 & U. minor & $701 \mathrm{~m}$ \\
\hline Štúrovo - Železničný Rad & in front of railway station & $47.799^{\circ} \mathrm{N}$ & $18.679^{\circ} \mathrm{E}$ & 2 & U. minor & $120 \mathrm{~m}$ \\
\hline Tešmácka Cesta & near road & $48.075^{\circ} \mathrm{N}$ & $19.007^{\circ} \mathrm{E}$ & 3 & U. minor & $134 \mathrm{~m}$ \\
\hline Vinohrady nad Váhom & village gardens & $48.340^{\circ} \mathrm{N}$ & $17.760^{\circ} \mathrm{E}$ & 2 & $U$. minor & $160 \mathrm{~m}$ \\
\hline Vrkúň & edge of forest & $47.931^{\circ} \mathrm{N}$ & $17.607^{\circ} \mathrm{E}$ & 1 & U. laevis & $116 \mathrm{~m}$ \\
\hline Vysoká & forest near lake & $48.401^{\circ} \mathrm{N}$ & $18.777^{\circ} \mathrm{E}$ & 1 & Ulmus spp. & $455 \mathrm{~m}$ \\
\hline Žiar nad Hronom & near pond & $48.580^{\circ} \mathrm{N}$ & $18.870^{\circ} \mathrm{E}$ & 1 & U. minor & $248 \mathrm{~m}$ \\
\hline Žibritov & forest & $48.389^{\circ} \mathrm{N}$ & $19.022^{\circ} \mathrm{E}$ & 1 & U. laevis & $500 \mathrm{~m}$ \\
\hline
\end{tabular}

between 2014 and 2015. It was also not found in northern part of Slovakia. It is a bit surprising that the species was not found practically in whole Eastern Slovakia in spite of the fact that the first record in the country came from there. One from the possible explanations of this may be a misidentification of $A$. leucopoda in 2007 made based on only one female specimen collected from oak leaves (7). Other reasons cannot be excluded either. Plots with occurrence of $A$. leucopoda and their characteristics are shown in Table 2.
The records of $A$. leucopoda show that the species mainly occurs in lowlands and river basins and, apparently, spreads along larger Slovakian rivers. In the river valleys it spreads from the south to the north. The records above support Blank et al. (2014) (34) who showed that A. leucopoda is frequent in floodplain forests along the Danube river separating Slovakia and Hungary. In 2003, the pest was first reported from the village Dejtár (Hungary) only $2.5 \mathrm{~km}$ from the border between the two countries (7). Also, A. leucopoda was often found on the Slovakian side 
of the Danube basin, and along rivers flowing into the Danube, namely the river Hron and Ipel'. These two rivers at least considerably support the northerly spread of this species (Figure 1). A. leucopoda occurred in the southern areas more frequently than in the northern (mountainous) ones. The plots Bojnice and Nitrianske Rudno were shown to be the northernmost localities in Slovakia with the documented occurrence of $A$. leucopoda. They both lie only $100 \mathrm{~km}$ from the location Dejtár in Hungary where the pest was reported for the first time in Europe (together with one place in Poland) already in 2003 (7). The spread of the pest from Northern Hungary into the Slovakia cannot be definitively confirmed by our data, but also cannot rejected especially if frequent occurrence of the pest was found in Danube basin in southern Slovakia, only few kilometers far from Hungarian village Dejtár. There is no information on the occurrence and dispersal of the species from the period between 2009 and 2014, so we do not know how fast and far (and from which points of introduction) it was spreading during this time. The pest had already been reported from many countries, located northwest from Slovakia, before this monitoring program took place (34), therefore the arrival of the sawfly from (also) other directions (i.e. from the north/west to the south/east) may not be excluded either.

At most plots in Slovakia, the population densities of A. leucopoda were low, the species caused only insignificant damage to elm trees. Only the slight damage to leaves is also known from Bulgaria (20) and Serbia (16). In Slovakia, more severe tree defoliations of trees were rarely documented. Higher level of infestation and more serious damage to leaves was observed only near Gabčíkovo and between Šahy and Slovenské Ďarmoty, where defoliation of some $U$. minor trees reached up to 20-30\%. In Germany, at most investigated localities only low levels of the pest population were found in 20132014, with insignificant damage to the hosts. Serious defoliation reached $50-70 \%$, has been recorded at one plot - Schlieben (Brandenburg) (34). Based on the evidence from Hungary, Romania, Italy and Germany, the pest has a potential to cause complete defoliation of elm trees ( 7 , 11, 23).

Table 2. Infestation of elm trees by A. leucopoda.

\begin{tabular}{|c|c|c|c|c|}
\hline Tree species & $\frac{\frac{0}{0}}{\frac{0}{2}}$ & 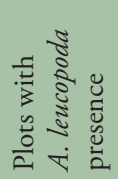 & 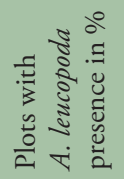 & 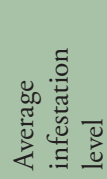 \\
\hline$U$. minor & 26 & 23 & 88.4 & 1.53 \\
\hline U. laevis & 19 & 4 & 21.1 & 0.21 \\
\hline U. spp. & 4 & 4 & 100.0 & 1.25 \\
\hline U. glabra & 4 & 0 & 0 & 0 \\
\hline Total & 53 & 31 & - & - \\
\hline
\end{tabular}

\section{Host selection}

Natural hybridization and planting of non-native hybrids of elm trees in Slovakia make the taxonomy of elm species rather complex and therefore determination of particular species difficult. At 53 plots, elm trees species were identified. In total, three elm species, $U$. minor, $U$. laevis and U. glabra, were documented. Considering the performance of $A$. leucopoda on particular hosts, $U$. minor was infested much more (average IL 1.53) than U. laevis (average IL 0.21). However, A. leucopoda was not found on U. glabra at all. U. glabra is a sub-mountain/mountain species and cool mountain climate could limit the occurrence of $A$. leucopoda on this elm species, especially in the northern areas of Slovakia (Table 2).

In Europe, A. leucopoda larvae may feed on different species of elm trees including a variety of ornamental cultivars. In Romania, average defoliation of individual trees ranged from $74 \%$ to $98 \%$ and U. glabra was infested. In Hungary defoliation of $U$. minor and $U$. pumila trees reached up to $100 \%$, larvae and cocoons were collected also from $U$. pumila var. arborea. Larvae or cocoons of A. leucopoda were collected from U. glabra, U. laevis and U. minor in Austria (7). Recently, from Hungary is reported heavy infestation of Siberian elm (U. pumila) with $A$. leucopoda in 2012 (35). During monitoring of the pest in Germany, larvae, feeding traces and cocoons were frequently found on the native elm species U. minor and U. glabra, whereas none sighs of presence were detected on $U$. laevis (34). In 2015, various stages of $A$. leucopoda have been found on the U. minor in Bulgaria (20). In European part of Russia larvae develop on various species of the genus Ulmus, preferring the Siberian elm U. pumila (21). In the Donetsk region in 2014 and in the Middle Vilga Region the same tree species was also heavily defoliated $(22,23)$. Defoliation by $A$. leucopoda could significantly decrease the resistance of infested trees against fungal pathogens and bark beetles, as in the case of other leaf eating insects (36, 37), as well as their aesthetics value in urban areas.

\section{Occurrence of A. leucopoda related to altitude}

A. leucopoda and its damages from 2014 and 2015 (n = 31) was recorded in altitudes between $108 \mathrm{~m}$ (Kameničná) and $701 \mathrm{~m}$ (Štiavnické Bane). Distribution of the infestation levels by altitude is displayed in Figure 2. In Europe, A. leucopoda was recorded only rarely above 500-600 m a.s.l. In Austria, it was found between 160$580 \mathrm{~m}(7,34)$, in Italy between $21-678 \mathrm{~m}$ (11) and in Bulgaria between 280-680 m a.s.l. (20).

Infestation levels: IL1 (low), IL3 (moderate), IL3 (high infestation). Median, interquartile range and extreme values including outliers (circle).

Figure 2 indicates the negative trend of relationship between the level of infestation and altitude. The mean 


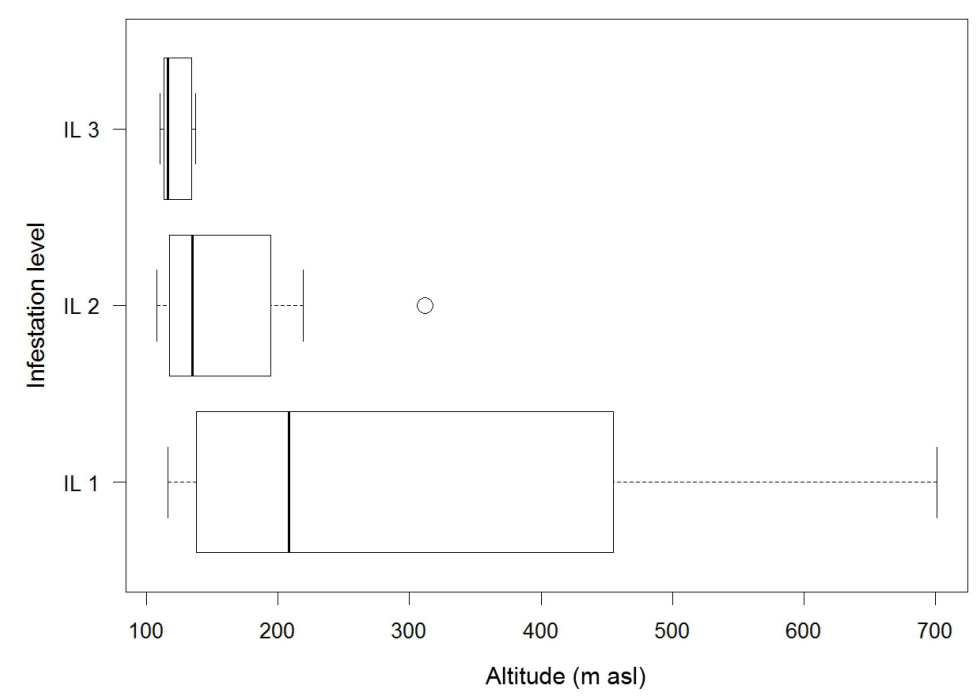

Figure 2. Infestation of elm trees by A. leucopoda by altitude $(n=31)$.

altitude of group of highly infested trees (IL 3) was 121 $\mathrm{m}$ a.s.l., mean altitude of moderately infested trees (IL 2) was $160 \mathrm{~m}$ a.s.l. and mean altitude of the group of low infestation level (IL 1) was $303 \mathrm{~m}$ a.s.l. The mean altitude of the plots of taken samples was $239 \mathrm{~m}$.

The Kruskal-Wallis Test $(\mathrm{H}=10.843, \mathrm{df}=2$, $\mathrm{p}$-value $=0.004)$ showed there is a significant difference between the IL groups. We used the Dunn's test to determine which group significantly differs from the others. The groups compared by the Dunn's test on a pairwise basis are shown in Figure 3.

The IL groups compared on a pairwise basis are indicated on the left-hand side of the chart. A vertical line indicates the 0.05 threshold.
From Figure 3 it can be seen that there is a significant difference $(p<0.005)$ between the altitude of IL3 and IL1 group. There were no significant differences found between other group comparisons (IL $2-$ IL1 $(p<0.089)$ and IL3 - IL2 $(p<0.532)$ ). The difference in mean altitude between IL1 and IL3 group was $182 \mathrm{~m}$ a.s.l., between IL 1 and IL 2 was $142 \mathrm{~m}$ a.s.l. and difference in mean altitude between IL2 and IL3 groups was $39 \mathrm{~m}$ a.s.l.

The results suggest that the invasive sawfly $A$. leucopo$d a$ has established in Slovakia, Central Europe. The establishment of this successful invader is documented by the records the larval traces on the leaves of elm trees (two species) at 31 different plots and, also, by the records of larvae, pupae and adults, mostly in the southwestern part

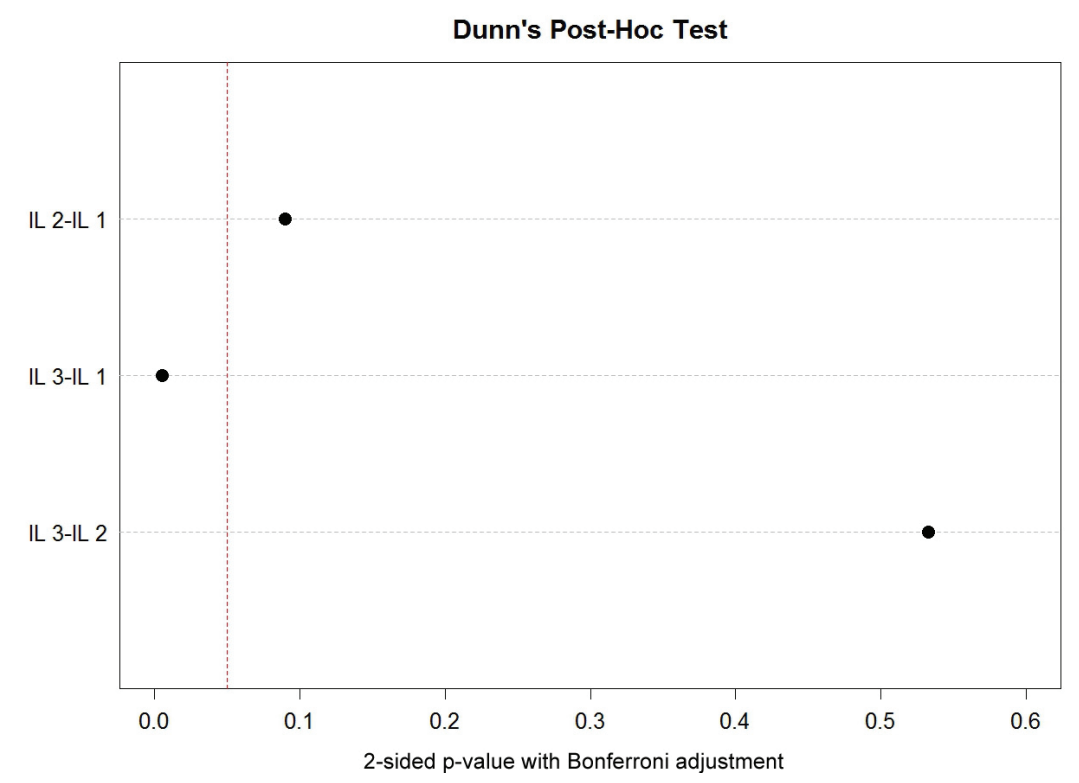

Figure 3. Dot chart of Dunn's post-hoc test. 
of this country. Although A. leucopoda tends to spread further to the north, its occurrence in the northern areas is limited at the present moment. As this invasive pest species has potential as a defoliator of elm trees, relation with fungal pathogens and bark beetle associates of elm trees in forests and urban areas need to be studied in more detail.

Acknowledgements: This work was supported by the $S K$ ERDF-funded operational programme Research and Development under Grant Centre of Excellence for Biological Methods of Forest Protection [ITMS: 26220120008]. It was also supported by the Slovak Research and Development Agency based on the agreement no. APVV-0707-12 Research of Disturbance Factors Affecting Long Lasting Development of Slovak Forest Health, on the agreement no. APVV-140567 Information and Warning System for Invasive Organisms in Forests and Urban Areas and on the agreement no. APVV-15-0348 New methods in Integrated Forest Protection Incorporating the Use of Entomopathogenic fungi, and on the agreement no. APVV-15-0531 Web GIS application for monitoring of harmful pests in forests of Slovakia. This work was also supported by the MPRV SR based on the item no. 08V0301 Research and Development for Innovation and Support of the Competitiveness of Forestry.

\section{REFERENCES}

1. ROQUES A 2010 Taxonomy, time and geographic patterns. Chapter 2. In: Roques A et al. (Eds) Alien terrestrial arthropods of Europe. BioRisk 4 (1): 11-26.

2. SIVICEK P, HRUBÍK P, JUHÁSOVA P 1997 Verbreitung der Rosskastanienminiermotte in der Slovakei. Forstschutz-Aktuell 21:

3. ZÚBRIK M, KUNCA A, TURČÁNI M, VAKULA J, LEONTOVYČ R 2006 Invasive and quarantine pests in forests in Slovakia. OEPP/EPPO Bulletin 36: 402-408.

https://doi.org/10.1111/j.1365-2338.2006.01025.x

4. GALKO J 2013 First record of the ambrosia beetle, Xylosandrus germanus (Blandford, 1894) (Coleoptera: Curculionidae, Scolytinae) in Slovakia. Lesnícky časopis - Forestry Journal 58 (4): 279

5. KENIS M, NACAMBO S, LEUTHARDT F L G, DOMENICO F D, HAYE T, 2013 The box tree moth, Cydalima perspectalis, in Europe: horticultural pest or environmental disaster? Aliens: The Invasive Species Bulletin 33: 38-41

6. ROY H E, BROWN P M J, ADRIAENS T, BERKVENS N, BORGES I, CLUSELLA-TRULLAS COMONT R F, DE CLERCQR, ESCHEN R, ESTOUP A, EVANS E W, FACON B, GARDINER M M, GIL A, GREZ A A, GUILLEMAUD T, HAELEWATERS D, HERZ A, HONEK A, HOWE A G, HUI C, HUTCHISON W D, KENIS M, KOCH R L, KULFAN J, LAWSON HANDLEY L, LOMBAERT E, LOOMANS A, LOSEY J, LUKASHUK A O, MAES D, MAGRO A, MURRAY K M, SAN MARTIN G, MARTINKOVA Z, MINNAAR I A, NEDVED O, ORLOVA-BIENKOWSKAJA M J, OSAWA N, RABITSCH W, RAVN H P, RONDONI G, RORKE S L, RYNDEVICH S K, SAETHRE M G, SLOGGETT J J, SOARES A O, STALS R, TINSELY M C, VANDEREYCKEN A, VAN WIELINK P, VIGLÁŠOVÁ S, ZACH P, ZAKHAROV I A, ZAVIEZO T, ZHAO Z 2016 The harlequin ladybird, Harmonia axyridis: global perspectives on invasion history and ecology. Biological Invasions 18 (4): 997-1044
7. BLANK S M, HARA H, MIKULÁŠ J, CSÓKA G, CIORNEI C, CONSTANTINEANU R, CONSTANTINEANU I, ROLLER L, ALTENHOFFER E, HUFLEJT T, VÉTEK G 2010 Aproceros leucopoda (Hymenoptera: Argidae): An East Asian pest of elms (Ulmus spp.) invading Europe. European Journal of Entomology 107: $357-367$

8. TAKEUCHI K 1939 A systematic study on the suborder Symphyta (Hymenoptera) of the Japanese Empire (II). Tenthredo 2: 393-439

9. WU X Y, XIN H 2006 A new record of the genus Aproceros Malaise (Hymenoptera: Argidae) from China. Entomotaxonomia 28 (4): $279-280$

10. ZHELOCHOVTSEV A, ZINOVJEV A $1995 \mathrm{~A}$ list of the sawflies and horntails (Hymenoptera, Symphyta) of the fauna of Russia and adjacent territories. Entomological Review 74: 395-415 (in Russian)

11. ZANDIGIACOMO P, CARGNUS E, VILLANI A 2011 First record of the invasive sawfly Aproceros leucopoda infesting elms in Italy. Bulletin of Insectology 64: 145-149

12. KRAUS M, LISTON AD, TAEGER A 2011 Die invasive ZickZack-Ulmenblattwespe Aproceros leucopoda Takeuchi, 1939 (Hym., Argidae) in Deutschland. DGaaE Nachrichten 25: 117-119

13. DE GROOT M, HAUPTMAN T, SELJAK G 2012 The first record of the invasive "zigzag" sawfly, Aproceros leucopoda (Hymenoptera: Argidae) in Slovenia. Gozdarski Vestnik 70(1): 3-7 (in Slovenian)

14. MATOŠEVIĆ D 2012 First record of elm sawfly (Aproceros leucopoda), new invasive species in Croatia. Šumarski list 136: 57-61 (in Croatian)

15. BOEVÉ J L 2013 First record in Belgium of the invasive sawfly Aproceros leucopoda (Hymenoptera, Argidae) and some related ecological data. Bulletin de la Société Royale Belge d'Entomologie 149: 217-221

16. GLAVENDEKIĆ M, PETROVIĆ J, PETAKOVIĆ M 2013 Alien invasive species Aproceros leucopoda Takeuchi (Hymenoptera: Argidae) - Elm pest in Serbia. Shumarstvo 1-2: 57-66 (in Serbian)

17. MOL A, VONK D 2014 De iepenzigzagbladwesp: een nieuwe exoot in Nederland. http://www.natuurbericht.nl/?id=12191 (accessed on 05. 05. 2016).

18. JURÁŠKOVÁ M, HRADIL K, MACEK J 2014 Pilatěnka Aproceros leucopoda - nový invazní škůdce v České republice. Rostlinolékař 3: 21-23 (in Czech)

19. MIHAILOVA J 2015 Aproceros leucopoda - jauns gobu kaitēklis Latvijā. http://www.vaad.gov.lv/21/section.aspx/6937 (accessed on 05. 05. 2016)

20. DOYCHEV D 2015 First record of the invasive Elm sawfly Aproceros leucopoda Takeuchi (Hymenoptera: Argidae) in Bulgaria. Silva Balcanica 16 (1): 108-112

21. SHCHUROV V I, GNINENKO Y I, LENGESOVA N A, GNINENKO M Y 2012 Aproceros leucopoda in the European part of Russia, Zashchita i karantin rasteniy 2: 37-38 (in Russian)

22. LENGESOVA N A, MISHCHENKO A V 2013 Biology, ecology and molecular characterization of Aproceros leucopoda (Takeuchi, 1939) (Hymenoptera: Argidae), pest of elms in the Middle Volga Region. Caucasian Entomological Bulletin 9 (1): 163-167 (in Russian)

23. MARTYNOV V V, NIKULINA T V 2016 New invasive phytophagous insects in woods and forest plantings of Donbass. Caucasian Entomological Bulletin 12 (1): 41-53 (in Russian)

24. BRASIER C M 1979 Dual origin of recent Dutch elm disease outbreaks in Europe. Nature 281: 78-80. https://doi.org/10.1038/281078a0

25. BRASIER C M 1991 Ophiostoma novo-ulmi sp. nov., causative agent of the current Dutch elm disease pandemics. Mycopathologia 115: 151-161. https://doi.org/10.1007/BF00462219

26. WEBBER 1981 A natural biological control of Dutch elm disease. Nature 292: 449-451. https://doi.org/10.1038/292449a0 
27. LEONTOVYČ R 1992 Importance of the genus Ophiostoma in the current ecological conditions in Slovakia. In: Holubová V, Prášil K (ed) Ophiostomatales - výsledky současného taxonomického a fytopatologického výskumu. Zborník referátov ČSAV Praha, ČSVSM, p. 35-49 (in Slovak)

28. VAKULA J, ZÚBRIK M, KUNCA A, DUBEC M, FINĎO S, GALKO J, GUBKA A, KAŠTIER P, KONÔPKA B, KONÔPKA J, LALKOVIČ M, LEONTOVYČ R, LONGAUEROVÁ V, MALOVÁ M, NIKOLOV CH, PAVLENDOVÁ H, RELL S 2015 New methods in the forest protection. NLC, Zvolen, p 292 (in Slovak)

29. SANTINI A, FACCOLI M 2013 Dutch elm disease and elm bark beetles: a century of association. iForest - Biogeosciences and Forestry

30. VÉTEK G, MIKULÁS J, CSÓKA G Y, BLANK S M 2010 The zigzag elm sawfly (Aproceros leucopoda Takeuchi, 1939) in Hungary. Növényvédelem 46 (11): 519-521 (in Hungarian)

31. PAGAN J, RANDUŠKA D 1988 Atlas drevín 2. Obzor, Bratislava, p 408 (in Slovak)

32. R CORE TEAM 2016 R: A Language and Environment for Statistical Computing. R Foundation for Statistical Computing, Vienna, Austria. https://www.R-project.org/.
33. ALBERTI G 2016 'plot.kw': R function for visually displaying Kruskal-Wallis test's results, Languages: R, Repository: http://cainarchaeology.weebly.com/r-function-for-visually-displaying-kruskal-wallis-test.html

34. BLANK S M, KÖHLER T, PFANNENSTILL T, NEUENFELDT N, ZIMMER B, JANSEN E, TAEGER A, LISTON A D 2014 Zig-zagging across Central Europe: recent range extension, dispersal speed and larval hosts of Aproceros leucopoda (Hymenoptera. Argidae) in Germany. Journal of Hymenoptera Research 41: $57-74$

35. VÉTEK G, PAPP V, FAIL J, LADÁNYI M, BLANK S 2016 Applicability colored traps for the monitoring of the invasive zigzag elm sawfly, Aproceros leucopoda (Hymenoptera: Argidae). Acta Zoologica Academiae Scientiarum Hungaricae 62 (2): 165-173. https://doi.org/10.17109/AZH.62.2.165.2016

36. PATOČKA J, KRIŠTÍN A, KULFAN J, ZACH P 1999 Die Eichenschädlinge und ihre Feinde. SAV Zvolen, p 396

37. KUNCA A, ZÚBRIKM, GALKO J, VAKULA J, LEONTOVYČ R, KONÔPKA B, NIKOLOV CH, GUBKA A, LONGAUEROVÁ V, MALOVÁ M, KAŠTIER P, RELL S, 2015 Salvage felling in the Slovak forests in the period 2004-2013. Lesnícky Časopis - Forestry Journal 61 (3): 188-195 